This item was submitted to Loughborough's Research Repository by the author.

Items in Figshare are protected by copyright, with all rights reserved, unless otherwise indicated.

\title{
Structural breaks and twin deficits hypothesis in African countries
}

PLEASE CITE THE PUBLISHED VERSION

http://dx.doi.org/10.1007/s10644-014-9154-2

\section{PUBLISHER}

(C) Springer Science+Business Media New York

\section{VERSION}

AM (Accepted Manuscript)

\section{PUBLISHER STATEMENT}

This work is made available according to the conditions of the Creative Commons Attribution-NonCommercialNoDerivatives 4.0 International (CC BY-NC-ND 4.0) licence. Full details of this licence are available at: https://creativecommons.org/licenses/by-nc-nd/4.0/

\section{LICENCE}

CC BY-NC-ND 4.0

\section{REPOSITORY RECORD}

Ahmad, A.H., and Olalekan B. Aworinde. 2019. "Structural Breaks and Twin Deficits Hypothesis in African Countries”. figshare. https://hdl.handle.net/2134/16843. 


\title{
Structural Breaks and Twin Deficits Hypothesis in African countries
}

\author{
Ahmad Hassan Ahmad*† Olalekan Bashir Aworinde ${ }^{\ddagger}$
}

\begin{abstract}
The study examines the twin deficits hypothesis in a sample of twelve African countries for the period between 1980 and 2009. These countries have experienced both the current account and the fiscal deficits, among others, that prompted an introduction of structural reforms. The paper explores long-run relationship between the series and their short-run dynamics within the context of endogenously determined structural breaks. The identified dates are generally associated with external factors that include commodity price boom and burst cycles that the countries heavily depend on. The estimated results for eight of the countries indicate that there is a positive relationship between the current account and fiscal deficits and therefore, support the twin deficits hypothesis. Results for the remaining four countries of Ethiopia, Kenya, South Africa and Uganda, on the other hand, show that the relationship between the two is negative.
\end{abstract}

Key Words: Fiscal deficits, Current account deficits, Structural Breaks, African countries

JEL Classification: H60, H62, C22

\footnotetext{
${ }^{*}$ School of Business \& Economics, Loughbrough University, Leicestershire, LE11 3TU, United Kingdom, A.H.Ahmad@lboro.ac.uk

${ }^{\dagger}$ We are very grateful to the editor and acknowledge the anonymous reviewers' useful and constructive comments.

${ }^{\ddagger}$ Department of Economics, University of Bath, Bath, BA2 7AY \& College of Social and Management Sciences, Tai Solarin University of Education, Ijebu-Ode, Nigeria.
} 


\section{Introduction}

Over the past two decades, the widening fiscal deficits and the current account imbalances in both developed and developing countries have generated concerns largely because they are seen as among the main measures of macroeconomic performance of a country. This has been further highlighted by the recent financial crisis that resulted in sovereign debts crisis of some Euro Area countries that even threatened the survival of the union. This paper investigates the relationship between the fiscal and the current account deficits in African countries. These countries rely on a few number of primary commodities for their exports, which are very vulnerable to terms of trade shocks. These shocks have important effects on both the countries' current account balances as well as their public expenditure. For about three decades now that some of these countries have introduced economic reforms to tackle among other things, these two deficits. Therefore, understanding relationship between these series will shed more light on the appropriate policies needed to be adopted by these countries to address these issues.

Theoretical literature on the twin deficits can be classified into four groups. The first group is based on the Keynesian absorption theory. It argues that an increase in the fiscal deficits would induce domestic absorption and thus, import expansion and thereby causing the current account deficits. The second one anchors its arguments on the Mundell-Fleming framework and it suggests that an increase in the fiscal deficits would have an upward pressure on the interest rates with a resultant capital inflows and exchange rate appreciation. The appreciated exchange rate would make exports less attractive, but will encourage imports, which will subsequently lead to the current account deficits. The third group's explanation is based on the risk premium hypothesis perspective. ${ }^{1}$ It argues that an appreciation of the real exchange rate increases the purchasing power of domestic income in terms of imported goods. This increases the relative value of financial, real estate and other assets held by the domestic residents. As a result, the domestic savings fall and a rise in consumption that will lead to a loss in competitiveness of the country's export in international markets, thereby causing the current account deficits. This implies that the exchange rate can impact on the twin deficits by changing relative price of non-tradeables and tradeables. Large government spending on non-tradeables such as services or the real estate sector can induce a real exchange rate appreciation which in turn increases consumption toward tradable thereby leading to the current account deficits. The fourth group is the one that is based on the Ricardian Equivalence Hypothesis, REH, of Barro (1974, 1989). The literature portends that the fiscal deficits and the current account balance are not related.

Empirical results on the twin deficits hypothesis have been mixed and largely inconclusive. For example, Egwaikhide (1999), Zietz and Pemberton (1990), Abell (1990), Corsetti and Muller (2006) and Grier and Ye (2009) found evidence that supports the twin deficits hypothesis whereas Enders and Lee (1990) reported that they found no relationship between the two, which supports the REH. Kim and Roubini (2008), on the other hand, found that the U.S. government budget deficits actually improve the U.S.

\footnotetext{
${ }^{1}$ See Bachman (1992) for details.
} 
current account balance.

This study contributes to this literature by investigating relationship between these two deficits in a sample of twelve African countries, which have largely been overlooked. These countries, as noted above, have experienced both the current account and the fiscal deficits that led to an introduction of economic reforms to address these deficits among others ${ }^{2}$. A notable exception in the sample is Botswana, which did not experience the problem until the recent financial crisis ${ }^{3}$. Secondly the paper differs from the existing literature in two main ways. First, relationship between the fiscal deficit and the current account deficit is examined by including real interest rate and real exchange rate in the estimated model to capture the transmission mechanism. Secondly, policy regime changes and shocks are likely to cause structural breaks, which this paper have explicitly addressed by using the Lee and Starzicich (2003) unit root tests that allow up to two structural breaks. Additionally, the paper used a flexible technique, the $\mathrm{Au}$ toregressive Distributed Lag (ARDL). This approach provides the necessary flexibility required for this analysis. First, it can test for long-run relationship between variables of different level of integration. Secondly, the identified structural breaks can be explicitly incorporated into the estimated model.

The rest of the paper is organised as follows. Section 2 discusses the methodology and the variables used in the paper. Section 3 presents the estimated results while Section 4 concludes.

\section{Methodology and Variables Description}

Based on the open economy macroeconomics, an increase in the fiscal deficit will give rise to an increase in the interest rate, that in turn causes the capital inflows and an appreciation of the real exchange rate. As a result of loss in international competitiveness, the domestic economy records current account deficit. From this theoretical point of view, five variables could be included in the model of the twin deficits hypothesis. They are measures of fiscal deficits and current account deficits, both of which are expressed as percentage of GDP. The remaining variables are real interest rates, real exchange rates and real GDP ${ }^{4}$. The real GDP is the key macro variable representing the broad economic performance, and it is included in the model to control for the cyclical components of the government budget deficit ${ }^{5}$. Thus, the twin deficit model can be represented as:

\footnotetext{
${ }^{2}$ Another reason for including these countries is availability of necessary data required for the analysis.

${ }^{3}$ Please refer to Section 3.3 for discussion on the economic charateristics of the countries in the sample.

${ }^{4}$ There might be a problem of simultaneity between the current account and the exchange rate, but the latter is included so as to capture the transmission mechanism of the twin deficits as in Kim and Roubini (2008).

${ }^{5}$ This paper also used a measure of output gap to control for the cyclical component of both the government deficit and the current account instead of the log of GDP based on the advice of the reviewers. However, the results obtained are not better than the ones reported in the paper based on log of real GDP. The latter is consistent with the approach adopted by Kim and Roubini (2008). Therefore, the results are not reported in the paper, but available on request.
} 


$$
C A_{t}=\beta_{0}+\beta_{1} \ln R G D P_{t}+\beta_{2} F D_{t}+\beta_{3} R I R_{t}+\beta_{4} R E R_{t}+\varepsilon_{t}
$$

where $C A$ is the current account deficits as a defined above, $R G D P$ is a measure of real income as a scale variable, $F D$ is the fiscal deficits expressed as a percentage of $G D P$, $R I R$ is the real interest rates and $R E R$ is the real exchange rate. Following a standard macro theory, estimates of $\beta_{1}, \beta_{2}$ and $\beta_{3}$ are expected to be positive. This is because an increase in the gross domestic product, fiscal deficits and interest rate are expected to lead to an increase in the current account deficits. An estimate of $\beta_{4}$ could be negative or positive. Given that the exchange rate is defined as the number of units of domestic currency per US dollar, an increase in the exchange rate means a depreciation of the domestic currency, raising the value of the foreign assets in terms of domestic currency. If this increase is perceived as an increase in wealth, then the demand for domestic money increases yielding a positive estimate of $\beta_{4}$. However, if an increase in the exchange rate induces an expectation of further depreciation of the domestic currency, public may hold less of domestic currency and more of foreign currency. In this case, an estimate of $\beta_{4}$ will be negative.

\subsection{Autoregressive Distributed Lag (ARDL) Testing Approach}

Autoregressive Distributed Lag (ARDL) approach was developed by Pesaran, Shin and Smith (2001) for testing cointegrating relationship. It has peculiar advantages over other symmetric cointegration tests. First, the ARDL approach can be applied to variables of different order of integration (Pesaran and Pesaran, 1997). Secondly, the ARDL approach could be used on small or finite sample size (Pesaran, et al., 2001). Thirdly, the short and long-run parameters are estimated concurrently. Fourthly, the approach can be used to accommodate the structural breaks identified in the variables used. In respect of these advantages, and coupled with the fact that the variables employed in this study are of different order of integration and relatively, a small sample size is used, the ARDL approach is the most suitable technique for this study.

Estimating an ARDL model involves four steps. First step is to examine the presence of cointegration using the bounds test procedure (Pesaran and Pesaran, 1997; Pesaran, Shin and Smith, 2001). Second, is to estimate the coefficient of the long run relationships identified in the first step. Third step is to estimate the short run coefficients while the final stage is to test for the stability of the model, by using the cumulative sum of recursive residuals (CUSUM) and cumulative sum of squared recursive residuals (CUSUMSQ). An ARDL representation of the model in equation (1) can be represented as: 


$$
\begin{aligned}
\Delta C A_{t}= & \beta_{0}+\sum_{i=1}^{p} \beta_{1} \Delta C A_{t-i}+\sum_{i=0}^{p} \beta_{2} \Delta \ln R G D P_{t-i} \\
& +\sum_{i=0}^{p} \beta_{3} \Delta F D_{t-i}+\sum_{i=0}^{p} \beta_{4} \Delta R I R_{t-i}+\sum_{i=0}^{n} \beta_{5} \Delta R E R_{t-i} \\
& +\delta_{1} C A_{t-1}+\delta_{2} \ln R G D P_{t-1}+\delta_{3} F D_{t-1} \\
& +\delta_{4} R I R_{t-1}+\delta_{5} R E R_{t-1}+\varepsilon_{t}
\end{aligned}
$$

where the variables are as defined in equation (1). In this set up, the null of no cointegration is defined by

$$
H_{0}: \delta_{1}=\delta_{2}=\delta_{3}=\delta_{4}=\delta_{5}=0
$$

and is tested against the alternative of

$$
H_{1}: \delta_{1} \neq 0, \delta_{2} \neq 0, \delta_{3} \neq 0, \delta_{4} \neq 0, \delta_{5} \neq 0
$$

by F-test. The asymptotic distribution of the F-statistic is non-standard irrespective of whether the variables are $I(0)$ or $I(1)$. Pesaran et al. (2001) provide two sets of appropriate critical values for the test. One set assumes all the variables are $I(1)$ and another that assumes all the variables are $I(0)$. These provide a band covering all possible classifications of the variables into $I(0)$ and $I(1)$ or even fractionally integrated. If the calculated F-statistic lies above the upper level of the band, the null is rejected, indicating existence of cointegration. If the F-statistic is below the lower critical bounds value, it implies failure to reject the null and none existence of cointegration. Where the F-statistic falls into the bounds, it suggests inconclusiveness.

\subsection{Modelling the Structural Breaks in Twin Deficits Model}

The identified structural break dates in the current account $(\mathrm{CAB})^{6}, T B_{1}$ and $T B_{2}$ are modelled by incorporating two dummy variables, $D U_{1}$ and $D U_{2}$ in the model specified in equations (3). The dummy variable $D U_{1}$ takes the value of zero from beginning to the first break date, $T B_{1}$, and becomes unity afterwards up to the second break date, $T B_{2}$ when $D U_{2}$ takes the value of unity or zero for the rest of the sample period. Therefore, the estimated model is given as:

$$
\begin{aligned}
\Delta C A_{t} & =\beta_{0}+\sum_{i=1}^{p} \beta_{1} \Delta C A_{t-i}+\sum_{i=0}^{p} \beta_{2} \Delta \ln R G D P_{t-i}+\sum_{i=0}^{p} \beta_{3} \Delta F D_{t-i} \\
& +\sum_{i=0}^{p} \beta_{4} \Delta R I R_{t-i}+\sum_{i=0}^{p} \beta_{5} \Delta R E R_{t-i}+\delta_{1} C A B_{t-1}+\delta_{2} \ln R G D P_{t-1} \\
& +\delta_{3} F D_{t-1}+\delta_{4} R I R_{t-1}+\delta_{5} R E R_{t-1}+\delta_{6} D U_{1 t}+\delta_{7} D U_{2 t}+\varepsilon_{t}
\end{aligned}
$$

\footnotetext{
${ }^{6}$ LM test was used to determine structural breaks in the series. For details about the test, see Lee \& Strazicich (2003).
} 
The parameters $\delta_{i}, i=1,2,3,4,5,6$ and 7 are the long-run multipliers, parameters $\beta_{1}$ to $\beta_{5}$ are the short-run multipliers, and $\varepsilon_{t}$ represents residuals.

\section{$3 \quad$ Data and Estimated Results}

\subsection{Sources and Definition of Data}

The data set consists of quarterly observations obtained from the International Financial Statistics (IFS), Government Finance Statistics (GFS) and the Balance of Payment Statistics (BOPS) of the International Monetary Fund, IMF, as well as the World Bank Development Indicators. GDP variables and fiscal deficits variables for some of the countries are sourced from the countries' central banks. The fiscal deficit $(F D)$ is defined as the difference between total government revenue and total government expenditure, expressed as percentage of GDP. The current account $(C A)$ is the sum of the balance of trade (exports minus imports of goods and services), net factor income (such as interest and dividends) and net transfer payments (such as foreign aid) and expressed as percentage of GDP. The real exchange rate is constructed from the nominal exchange rate using $R E R_{t}=E_{t}+P_{t}^{*}-P_{t}$, (all variable are in logs) where $R E R_{t}$ is the real exchange rate, $E_{t}$ is the nominal exchange rate, $P_{t}^{*}$ denotes foreign prices (the US CPI is used as a proxy), $P_{t}$ is the domestic CPI. The real interest rate $(R I R)$ is the long term interest rates adjusted for inflation whereas the $R G D P$ is the countries' real output. The sample period runs from 1980 to 2009, making a total of 120 observations for each country. The countries in the sample are Botswana, Cameroon, Egypt, Ethiopia, Ghana, Kenya, Morocco, Nigeria, South Africa, Tanzania, Tunisia, and Uganda. The criteria for choosing these countries include the size of gross domestic product, which these countries together accounted for about $75 \%$ of total African GDP in 2010 (see Ahmad, Harvey and Pentecost, 2011). Others are availability of data, relative economic and financial development as well as presence of capital markets

\subsection{Unit Roots Tests}

Table 1 reports results from the ADF test, which indicate that some variables are stationary $I(0)$ on levels in seven countries. These are Botswana, Cameroon, Egypt, Ethiopia, Ghana, Tunisia and Uganda. However, the results show that most of the variables are non-stationary $I(1)$ on levels, but stationary $I(0)$ on first differences. The ADF test, therefore, suggest that the variables in the sample are of different level of integration. The reported PP unit root test results indicate that most of the variables are non-stationary $I(1)$ on levels, but stationary $I(0)$ on first differences. However, some variables are found to be stationary $I(0)$ on levels in six countries of Egypt, Ghana, Kenya, South Africa and Tunisia. Over all, the results from both tests suggest that the variables are of different level of integration. 


\subsection{Structural Breaks and Country Characteristics}

The sample used for this study includes periods of economic difficulties and policy regime changes in most of the countries covered. These may result in structural breaks, which can have implication for unit root test. It is argued that presence of structural breaks in series may lead to false conclusions, given the inability of standard ADF and PP tests to capture structural breaks ${ }^{7}$. In order to address this, the LM Test of Lee and Strazicich (2003) that can accommodate up to two breaks was used to analyse the series ${ }^{8}$. The results are presented in Tables 2 to 5 . Specifically, the results are reported in column 7 of these tables. The results revealed that breaks were detected in all the series and most of the breaks took place around the 1980s and the 1990s, which coincide with a number of significant events that took place during the period. These include introduction of economic reforms in the 1980s as well as commodity booms and bursts experienced during the periods.

The economies in this sample are mostly dominated by agriculture, except Botswana, Nigeria and South Africa. The dominance of agriculture is not evenly distribution as for example; it accounts for about half of GDP in countries like Ethiopia, Tanzania and Uganda and constitutes up to $80 \%$ of their export earnings, while it contributes about $24 \%$ of Kenya's GDP. Mining is the dominant sector in Botswana and South Africa. Botswana is an important global diamond producer while South Africa is the world's largest producer of platinum with important quantity of gold and chromium. South Africa has the most developed financial system in the sample and currently the second largest economy in Africa behind Nigeria. Nigerian economy was agrarian until the early 1970s when petroleum sector became the most important sector that dominated both the exports and the government revenues. Cameroon is the only country in the sample that is a member of a monetary union, Central Africa CFA Zone. Unlike most of the countries in the sample, Cameroon recorded moderate inflation rate. Oil is increasingly becoming an important contributor to both its foreign exchange earnings as well as its GDP. The economy of Egypt is also dominated by oil sector. Ghana is rich in relatively diverse natural resources that include diamonds, gold as well as oil. It is also an important cocoa producing country. Morocco is the only country in the sample where service sector dominates the economy and accounts for up to half of its GDP, but service sector is important to a number of countries in the sample, although to a lesser degree. These include Ghana, Nigeria and South Africa.

The economies have enjoyed moderate growth rate in the 1960s. However, by the 1970s, most of the economies were confronted with economic problems that were caused by both domestic economic policies and external factors. Import substitution industrialization strategy was adopted in a number of these countries in the 1960s and the 1970s that include Cameroon, Egypt, Ghana and Nigeria. However, the strategy recorded very little success in terms of saving the countries' foreign reserves, raising level of employ-

\footnotetext{
${ }^{7}$ See Perron (1989) for full discussion on that.

${ }^{8}$ The apparent limitation of this approach is limiting the number of breaks to two. This therefore, points to the need for further research to explore possibility of more than two breaks and if that would affect the reported results.
} 
ment and transfer of technical know-how that the strategy intended to achieve. On the contrary, the countries ended up with non-productive industries that were acting as conduit that drained the public funds. The 1970s oil shocks and the commodity price burst recorded during the same decade were among the external factors that exacerbated the effects of the domestic policies. As a result, the economies resorted to external borrowing at variable interest rates, which brought about the burden of debt and interest rate payments. For example, external debt of Morocco was $\$ 11.6$ billion as at 1983 and that of Nigeria was $\$ 12.8$ billion for the same period, but these figures more than doubled to $\$ 30$ billion by 1989 for the latter. Decline in commodity prices in international markets, which the countries depend upon for their foreign exchange coupled with huge domestic expenditure portfolio, the countries' current account and fiscal deficits worsen. Consequently the countries were forced to introduce structural reforms, which were backed by the IMF and the World Bank in the 1980s and the 1990s. Notable exceptions in the sample are Botswana and South Africa. The former has recorded an impressive growth rate and was acknowledged for sound macroeconomic policy and good governance. It still remains the best performing economy on the continent (for example, see Acemoglu et al., 2002). Botswana has also a negligible amount of foreign debt.

Table 2 reports break dates for Botswana, Cameroon and Egypt. The identified break dates for Botswana are in the 1980s, the 1990s and the 2000s. These seems to coincide with some policy regime changes such as removal of exchange control, exchange rate devaluations and the introduction of trade liberalization. Fiscal expansionary policy of the late 1980s could be responsible for breaks identified in the fiscal deficit and the inflation series. The LM test has identified structural breaks in all the series for Cameroon and they are around the 1980s, the 1990s and the early 2000s. Commodity price burst (especially decline in price of cocoa, coffee and cotton) that occurred in the mid 1980s might be responsible for the 1980s breaks. The CFA zones ${ }^{9}$ of which Cameroon is a member, suffered from loss of competitiveness as a result of an overvalued currency and in January 1994, the currency was devalued by about $100 \%$. These changes have appeared to have been picked up by the tests. Other breaks are associated with structural reforms implemented by the country. Such as the slashing of civil servants' wages by over $60 \%$, privatisation of publicly owned industries and re-scheduling of foreign debt repayments. The identified break dates for Egypt are mostly in the 1980s and the 1990s. The former was the period when the country's main export price, oil, slumped from $\$ 34$ per barrel to $\$ 12$, precipitating series of economic problems that included fall in output, unemployment and a rise in inflation to over $20 \%$. The latter was dominated by reforms implementation that comprised removal of price control, reduction of subsidies as well as reduction of public sector dominance in manufacturing and other sectors.

Table 3 contains the LM test results for Ethiopia, Ghana and Kenya. Results for Ethiopia indicate that the identified break dates are around the 1990s and the early 2000s. The country is very vulnerable to commodity price changes as not only it is a predominantly agrarian economy, but almost depends on coffee as its main foreign

\footnotetext{
${ }^{9}$ There are two CFA zones (monetary unions) in Africa: the West African CFA Zone and the Central Africa CFA Zone. Cameroon belongs to the latter.
} 
exchange earner. In addition, the sector also experienced periodic droughts that affected its general economic performance. These developments seem to be responsible for the break dates identified in the 1990s. The latter period was dominated by structural reforms that included expansion of private sector participation, devaluation of the currency to improve its international competitiveness and market reforms that eliminated restrictions such as quotas. The break dates for the latter period appear to have captured these changes (for example, see Dercon, 2006). The cross border war of 1998 2000 with Eritrea has also significant effect on the country's fiscal deficit and inflation as indicated by the break dates. The identified break dates for Ghana were mostly around the 1980s. The effects of the 1960s and the 1970s collapsed of commodity prices were devastating to the economy and as a result, the country saw the 1980s as the most difficult decade in its economic history. These have been captured by the test as structural breaks were identified in all the series during the period. The LM test results for Kenya show that breaks were identified in all the series, which mostly centred around the 1990s with a few in the 1980s. The break dates were during the country's economic recession (1983-1993), which inappropriate agricultural policies were partly blamed for and the subsequent implementation of structural economic reforms.

Results of the LM test for Morocco, Nigeria and South Africa are presented in Table 4. The identified dates for Morocco coincide with the periods that the country experienced a huge fall in revenue and mounting external debt while the fiscal deficit rose to about $90 \%$ of its GDP. Subsequent reforms that included exchange rate devaluation and privatisation of public enterprises were implemented, which appear to be responsible for the breaks in the 1990s, particularly in the current account, the real exchange rates and the real interest rates. The break dates identified for Nigeria are in the 1980s, the 1990s and the 2000s. Most of these are due to policy regime changes in response of the economic problem that was caused by a collapse in oil prices, but aggravated by poor domestic economic policies. The country introduced series of economic reforms between 1986 and 1994. These covered almost all sectors of the economy, which included subsidy removal, huge public expenditure cut, liberalisation of foreign exchange market and trade. These had consequences on the economy's indicators such as employment and inflation. Rises in oil prices recorded in the 2000s seem to have significant effects on the country's fiscal deficit variable as indicated by the results. The economic sanctions imposed on South Africa during the apartheid era, which climaxed in the 1980s, had crippling effects on the economy. These have caused structural breaks in all the series, which have been captured by the test. The economic reforms introduced in the 1990s to promote balanced growth and re-distribution were responsible for the identified breaks in the 1990s.

Table 4 contains the LM test results for Tanzania, Tunisia and Uganda. Those of Tanzania show that breaks were detected in the GDP, the interest rate and the exchange rate variables, which coincided with the period of external debt crisis and the introduction of economic reforms. However, break dates in the fiscal and the current account deficits suggest that they are associated with the country's external debt crisis period between 1982 and 1989. Results for Tunisia suggest that most of the breaks took place 
in the 1980s and the 1990s. The country entered the decade of the 1980s with economic difficulties due to the dwindling public revenues and the mounting external debt. As a result the economy was bedevilled with escalating budget deficit, inefficiency in public enterprises as well as expansionary monetary policies that contributed to rise in the interest rates and the real exchange rate appreciation, which led to further deterioration of the current account deficit. These changes have been the causes for the identified breaks in the 1980s while those of the 1990s have captured the economic reforms implemented during the period. The break dates identified by the LM Test for Uganda show that the GDP, the fiscal deficits, the current account deficits, the exchange rate and the interest rate series have structural breaks both during the external debt crisis period and during the implementation of the reforms. Other notables events that have significant impact on the variables is the civil unrest of 1986 and the elections held in 2001 and 2006.

\subsection{Cointegration Test Results}

To conduct the bounds test for cointegration approach within the unrestricted error correction model (UECM) framework, the optimal lag needs to be determined. Following Lutkepohl (2005), the Schwarz Bayesian Criterion (SBC) was used for this purpose as it is found to perform better than other information criteria. The results for the $F$ bounds test are reported in Table 6, which imply that the null hypothesis of no cointegration among the variables in the model specified in equation (3) was rejected for all the countries at any conventional level. Therefore, these variables have long run relationship. Having found a long-run relationship between the fiscal deficits and the other variables, the long-run elasticities were estimated. Impact of real GDP, fiscal deficits, real interest rates and real exchange rates on current account were examined for each of the countries covered in the study. The empirical results for the model are obtained through normalizing the current account $(\mathrm{CA})$ in the short and long-run.

\subsection{The Long-Run Dynamics}

The estimated long-run coefficients (elasticities) for the estimated UECM model are presented in Tables 7 to 12. It is shown that in the long run, one per cent increase in the real GDP leads to $21.59,14.75,6.2,49.43,41.82,33.05,10.46$ and 18.29 decrease in the current account deficits in Botswana, Cameroon, Ghana, Kenya, Nigeria, South Africa, Tanzania and Uganda respectively. This could be interpreted as one per cent increase in country-specific productivity would lead to a decrease in the current account deficits. However, one per cent increase in the real GDP will lead to 4.23, 27.97, 36.14 and 1.67 increase in the current account deficits in Egypt, Ethiopia, Morocco and Tunisia. One per cent increase in the budget deficits will lead to 0.92, 0.04, 0.47, 0.16, 0.03, 0.34, 2.14 and 0.35 increases in the current account deficits in Botswana, Cameroon, Egypt, Ghana, Morocco, Nigeria, Tanzania and Tunisia. These are consistent with previously reported results by Beetsma et al (2007) and Abass et al (2010). Also, one per cent increase in budget deficits lead to $0.56,0.52,0.05$ and 0.52 decrease in the current account deficits in Ethiopia, Kenya, South Africa and Uganda. The evidence shows that the fiscal deficits 
have a positive and significant effect on the current account deficit in Botswana, Egypt, Nigeria and Tanzania and statistically insignificant in Cameroon, Ghana, Morocco and Tunisia. Fiscal deficits have a negative and statistically significant effect in Ethiopia and Kenya but not in South Africa and Uganda. This might be due to the effect of productivity shocks that was discuss in Busserie, Fratzscher and Mueller (2010), but it requires further investigation.

Effect of real interest rate on the current account are positive in Botswana, Ethiopia, Morocco, Nigeria and Uganda and negative in Cameroon, Egypt, Ghana, Kenya, South Africa, Tanzania and Tunisia. This, therefore, imply that one per cent increase in real interest rate leads to $1.62,0.6,0.8,0.09$ and 0.01 per cent increase in the current account deficit in Botswana, Ethiopia, Morocco, Nigeria and Uganda respectively. Conversely, one per cent increase in the real interest rate leads to $0.14,0.15,0.10,0.02,0.14,0.17$ and 0.47 decrease in the current account deficit in Cameroon, Egypt, Ghana, Kenya, South Africa, Tanzania and Tunisia, respectively.

On the effect of real exchange rate on the current account, the results show that one per cent increase in real exchange rate leads to $1.94,4.58,0.44,0.96,1.75$ and 0.99 per cent increase in the current account deficit for Cameroon, Egypt, Kenya, Nigeria, South Africa and Tunisia respectively. In these countries, the results suggest that real exchange rate depreciation improves their current account deficit as they become more competitive, which will lead to a rise in the quantity of their exports, thereby improving the current account deficit. Similarly, real exchange rate depreciation will lead to a rise in the cost of their imports, which will lead to a fall in demand for imports and consequently, improves their current account deficits. These results are consistent with the findings of other papers. For example, Algieri (2011) found significant long-run relationship between the real exchange rate and the fiscal policy in Russia.

Results for Botswana, Ethiopia, Ghana, Morocco, Tanzania and Uganda have also shown that real exchange rate depreciation has a positive impact on the countries' current account deficits. However, the results for this set of countries are not statistically significant. The results also reveal that the endogenous structural break dummy variables, $D U_{1}$ are positive and statistically significant in most of the countries with the exception of Cameroon and Egypt, where they are found to be insignificant. Those of Ethiopia and Morocco are both negative and statistically significant. Similarly, the second structural break date variables, $D U_{2}$ for all the countries, except for Egypt, Ethiopia and Morocco, are positive and statistically significant. However, they are negative in the other three and statistically insignificant in the case of Egypt. Real exchange rate has been found to have significant impact on even the current accounts of developed countries (for example, see Brissimis, et al , 2013).

It is clear from the foregoing that results for eight of the countries covered seem to support the twin deficit hypothesis. The countries are Botswana, Cameroon, Egypt, Ghana, Morocco, Nigeria, Tanzania and Tunisia. In general, it could be argued that some of the reasons why the twin deficits does not hold in some of the countries might be attributed to the structural differences across the economies and the role of productivity shocks in explaining the relationship between the budget and the current account deficits. 
For instance, in Ethiopia where it is found that an increase in fiscal deficits by one per cent will result in reducing the current account deficits by 0.56, the economy is predominantly agrarian and as such the household might exhibit a Ricardian behaviour, which may not allow the twin deficit hypothesis to hold (Brissimis, et al, 2012).

\subsection{Short-run Dynamics}

The short-run adjustment process is measured by the error correction term $E C M_{t-1}$ and it shows how quickly variables adjust back to equilibrium in responding to a shock. It is expected that the coefficient of $E C M_{t-1}$ should have a negative sign and be statistically significant. The reported results for the $E C M_{t-1}$ are $-0.3365,-0.1927,-0.1065$, $-0.1851,-0.1687,-0.1607,-0.1310,-0.1518,-0.4979,-0.0456,-0.1573$ and -0.1374 for the respective countries. Therefore, all the estimated coefficients have the correct signs and are highly significant. The results indicate that deviations from the current account balance equilibrium are rectified by about $33.65 \%, 19.27 \%, 10.65 \%, 18.51 \%, 16.87 \%$, $16.07 \%, 13.10 \%, 15.18 \%, 49.79 \%, 4.56 \%, 15.73 \%$ and $13.74 \%$ by the following quarter in Botswana, Cameroon, Egypt, Ethiopia, Ghana, Kenya, Morocco, Nigeria, South Africa, Tanzania, Tunisia and Uganda respectively. It is clear that the the adjustment processes are fast and significant for all the countries covered.

\subsection{Stability Test}

To check for the robustness of the results, CUSUM and CUSUMSQ tests proposed by Brown et al. (1975) are carried out and the results are reported in Figures 1. The tests are applied to the residuals of the estimated model. The CUSUM test is based on the cumulative sum of recursive residuals based on the first set of $N$ observations. It is updated recursively and is plotted against the break points. If the plot of CUSUM statistic stays within a 5\% significant level (portrayed by two straight lines whose equations are given in Brown et al. (1975), then the estimated coefficients are stable. Similar procedure is used to carry out the CUSUMSQ tests, which are based on the squared recursive residuals. It is evident from the reported results that the plots of CUSUM statistic were all within the $5 \%$ significant level, indicating that the estimated models are stable. However, the plots of CUSUMSQ for Kenya and Tanzania cross the critical value lines, indicating some instability in their current account deficits. This may not be very serious issue as the instability that was observed occurred in the late 1990s, but diminished over time, and by the 2000s the plots are within the critical value bounds. Also notable from the results is that the graphs for some countries differ. For example, the plots for South Africa start much earlier as compared to those of Botswana. This might be due to the period when the structural breaks occur. The ARDL approach plots the CUSUM and the CUSUMSQ from where the second structural breaks occur. For instance, the second structural break for Botswana's current account deficits variable occurred in the fourth quarter of 2004 and that of South Africa was recorded in the second quarter of 1988. Hence, the reason for the differences in the plots of CUSUM and CUSUMSQ for these countries. 


\section{Conclusion}

The purpose of this paper is to test for the twin deficit hypothesis in a sample of twelve African countries. The paper differs from previous studies in three ways: first, properties of the series were investigated using the Lee and Strazicich (2003) LM unit-root test procedure that endogenously detects up to two structural breaks. Previous studies have largely overlooked the issue of structural breaks. Secondly, the identified structural break dates were explicitly incorporated into the estimated model. No previous studies on the twin deficit hypothesis have explicitly modelled structural breaks in this manner, with a notable exception of Marashdeh and Saleh (2006). Thirdly, a flexible, robust econometric framework, the ARDL, was used to explore the long- run relationship between the series and to investigate their short-run dynamics.

The results from the LM Tests indicate presence of structural breaks in all the series in the sample and some of the contradictory results reported by the ADF and the PP unit root tests have appeared to be reconciled by the LM. This suggests influence of structural breaks, which the LM test is able to account for. The identified break dates were generally associated with external shocks that included oil price shocks and commodity price boom and burst cycles of which the countries highly dependent on for their foreign exchange earnings. Other identified break dates are due to internal factors, such as policy regime changes, particularly, during the implementation of structural economic reforms of the 1980s and the 1990s.

Results from the ARDL indicate that the fiscal deficit, the real GDP, the current account, the real interest rates and the real exchange rates in the twelve African countries studied have long-run relationship as evidenced by the presence of cointegration. The short-run dynamics of the model estimated for all the countries show that the systems adjust back to equilibrium fairly quickly and they are statistically significant. Results for the long run coefficients obtained from the bound test show that there is a positive relationship between the fiscal deficits and the current account deficits in Botswana, Cameroon, Egypt, Ghana, Morocco, Nigeria, Tanzania and Tunisia. Therefore, the results for these countries support the twin deficit hypothesis that a strong relationship between the budget deficit and the current account deficit exists for the period studied. A negative relationship between fiscal deficits and current account deficits is found for Ethiopia, Kenya, South Africa and Uganda.

\section{References}

[1] Abbas, S. M. Ali; Bouhga-Hagbe, Jacques; Velloso Ricardo; Fatas Antonio J \& Paolo Mauro. 2010. Fiscal Policy and the Current Account. Technical report International Monetary FundWorking Papers, pp. 1-30.

[2] Abell, John D. 1990. "The Role of the Budget Deficit during the Rise in the Dollar Exchange Rate from 1979-1985." Southern Economic Journal 57(1):66-74. 
[3] Acemoglu, D., Johnson, S. and Robinson, J. A. (2002). 'An African success: Botswana', in (D. Rodrik ed.) Analytic Development Narratives, Princeton: Princeton University Press.

[4] Ahmad, A.H., David I. Harvey \& Eric J. Pentecost. 2011. "Exchange rate regime verification: An alternative method of testing for regime changes."Economics Letters 113(1):96-98.

[5] Algieri, B. (2011) "The Dutch Disease: Evidence from Russia", Economic Change and Restructuring, 44: 243 - 277.

[6] Bachman, Daniel David. 1992. "Why Is the U. S. Current Account Deficit so Large? Evidence from Vector Autoregressions." Southern Economic Journal 59(2):232-240.

[7] Barro, Robert J. 1974. "Are Government Bonds Net Wealth?" Journal of Political Economy 82(6):1095-1117. Barro, Robert J. 1989. "The Ricardian Approach to Budget Deficits." Journal of Economic Perspectives 3(2): 37-54.

[8] Beetsma Roel, Massimo Giuliodori \& Franc Klaassen. 2007. The Effects of Public Spending Shocks on Trade Balances in the European Union. Technical report University of Amsterdam Working Paper.

[9] Brissimis, S. N., Hondroyiannis, G., Papazoglou, C., Tsaveas, T. and Vasardani, M. A. (2013) "Current Account Determinants and External Sustainability in Periods of Structural Change", Economic Change and Restructural Change, 45, Issues 1-2, 71-95.

[10] Brissimis, S. N., Hondroyiannis, G., Papazoglou, C., Tsaveas, T. and Vasardani, M. A. (2013) "The Determinants of Current Account Imbalances in the Euro Area: A Panel Estimation Approach", Economic Change and Restructural Change, 46, 299 -319 .

[11] Busserie, Fratzscher and Mueller (2010), "Productivity Shocks, Budget Deficits and the Current Account", Journal of International Money and Finance 29(8), 15621579 .

[12] Corsetti, Giancarlo \& Gernot J. Müller. 2006. "Twin deficits: squaring theory, evidence and common sense."Economic Policy 21(48):597-638.

[13] Dercon, S (2006) Economic Reform, Growth and the Poor: Evidence from Rural Ethiopia, Journal of Development Economics, 81: 1, pp. 1-24.

[14] Egwaikhide, Festus O. 1999. "Effects of Budget Deficit on Trade Balance in Nigeria: A Simulation Exercise." African Development Review 2:265-289.

[15] Enders, Walter \& Bong-Soo Lee. 1990. "Current Account and Budget Deficits: Twins or Distant Cousins?" The Review of Economics and Statistics 72(3):373-81. 
[16] Grier, Kevin \& Haichun Ye. 2009. "Twin Sons of Different Mothers: The Long And The Short of The Twin Deficits Debate."Economic Inquiry 47(4):625-638.

[17] Khalid, Ahmed M. and Teo Wee Guan. 1999. "Causality tests of budget and current account deficits: Cross-country comparisons."Empirical Economics 24(3):389-402.

[18] Kim, Soyoung and Nouriel Roubini. 2008. "Twin deficit or twin divergence? Fiscal policy, current account, and real exchange rate in the U.S." Journal of International Economics 74(2):362-383.

[19] Lee, Junsoo \& Mark C. Strazicich. 2003. "Minimum Lagrange Multiplier Unit Root Test with Two Structural Breaks." The Review of Economics and Statistics 85(4):1082-1089.

[20] Lütkepohl, H. 2005. New Introduction to Multiple Time Series Analysis. Cambridge University Press, Cambridge.

[21] Marashdeh, H. and A. S Saleh. 2006. Revisiting Budget and Trade Deficits in Lebanon: A Critique. Technical report Department of Economics, University of Wollongong.

[22] Perron, P. (1989), "The great crash, the oil price shock, and the unit root hypothesis", Econometrica, 57, pp.1361-1401.

[23] Pesaran, H. M. and B Pesaran. 1997. Working with Microfit 4.0: Interactive Econometric Analysis. Oxford University Press.

[24] Pesaran, M. Hashem, Yongcheol Shin and Richard J. Smith. 2001. "Bounds testing approaches to the analysis of level relationships." Journal of Applied Econometrics $16(3): 289-326$.

[25] Saleh, Ali Salman. 2006. "Long-run linkage between budget deficit and trade deficit in Lebanon: Results from the UECM and Bounds tests." IIUM Journal of Economics and Management 14(1):29-48.

[26] Zietz, Joachim \& Donald K. Pemberton. 1990. "The U. S. Budget and Trade Deficits: A Simultaneous Equation Model."Southern Economic Journal 57(1):2334 . 


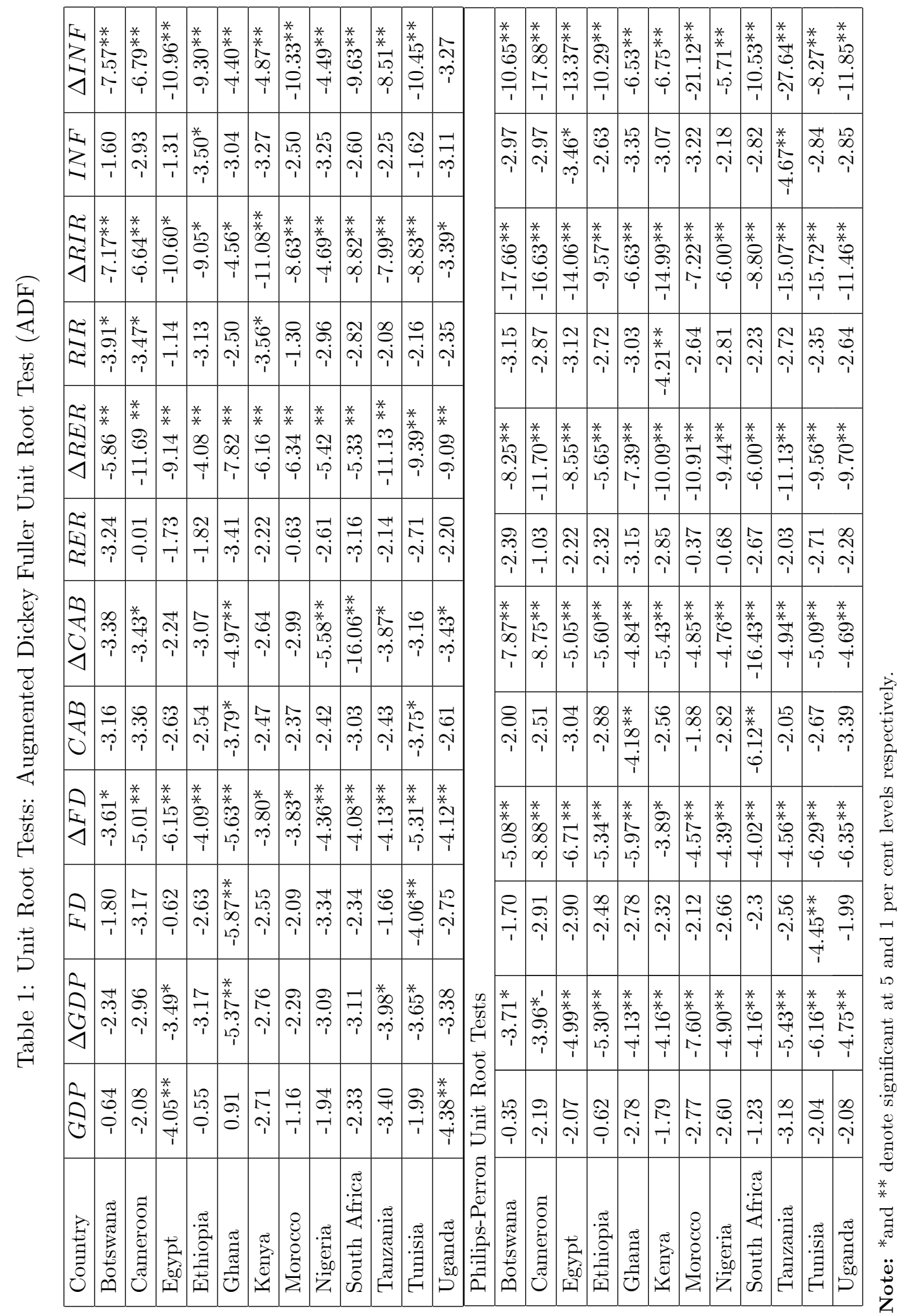



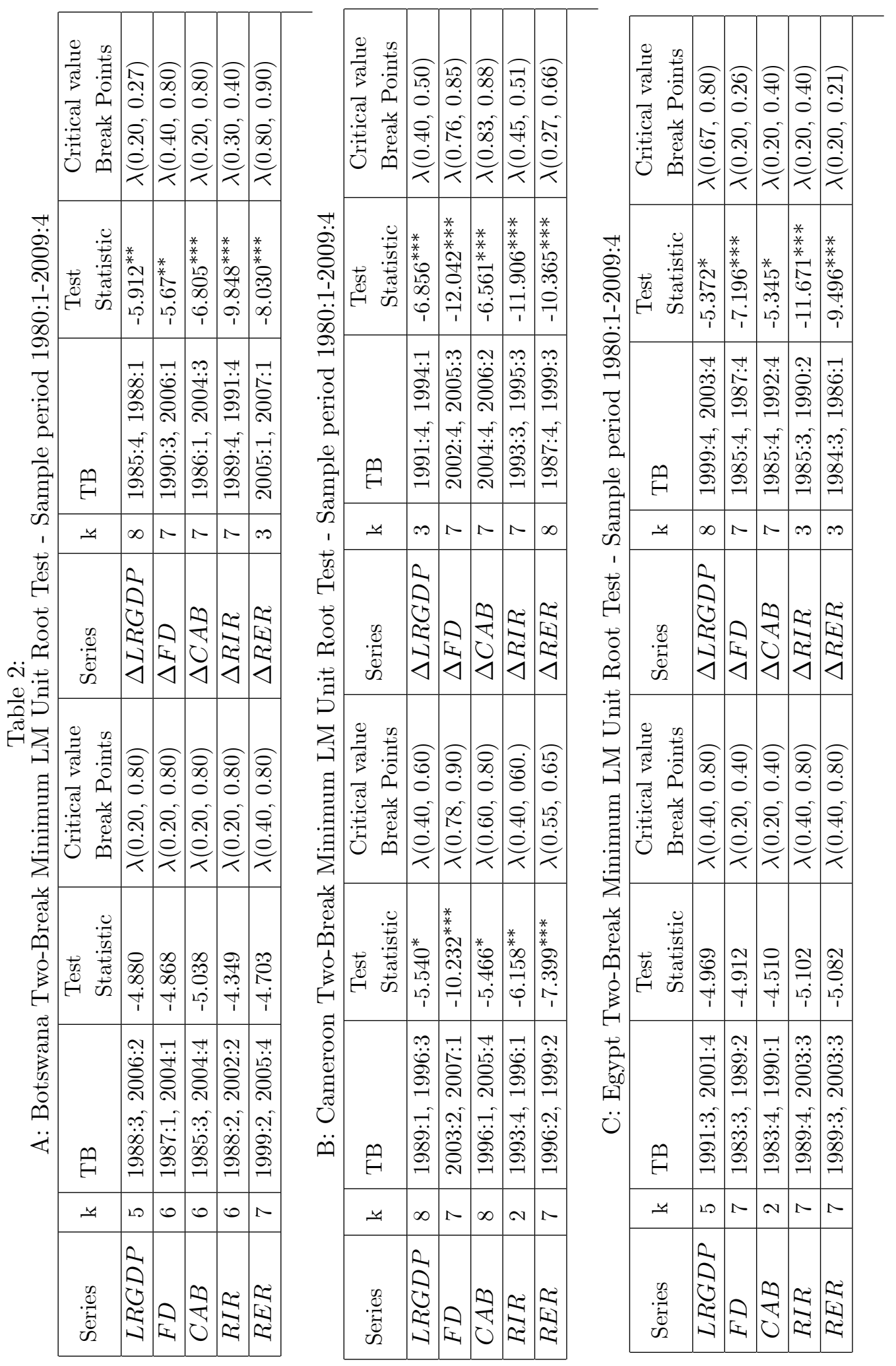

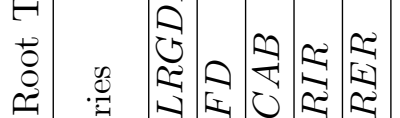

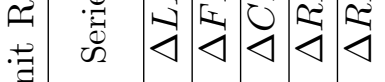

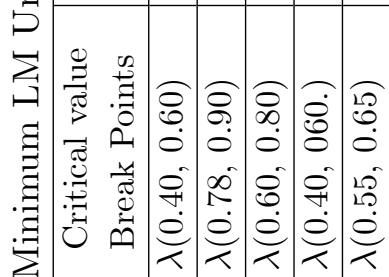

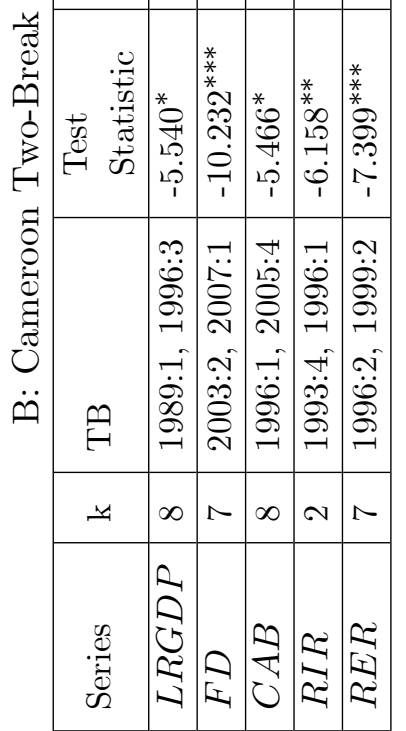

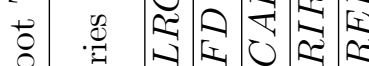

至

.

志䨔

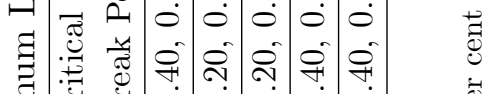

छ

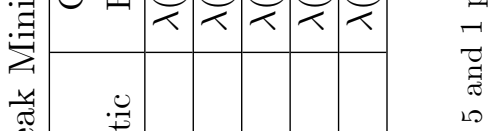

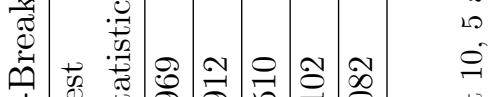

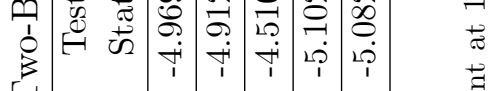

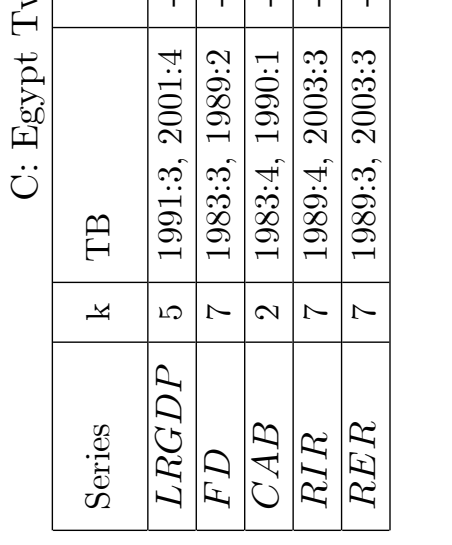

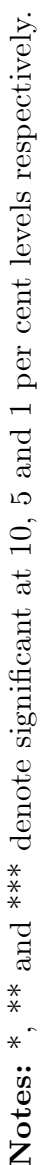



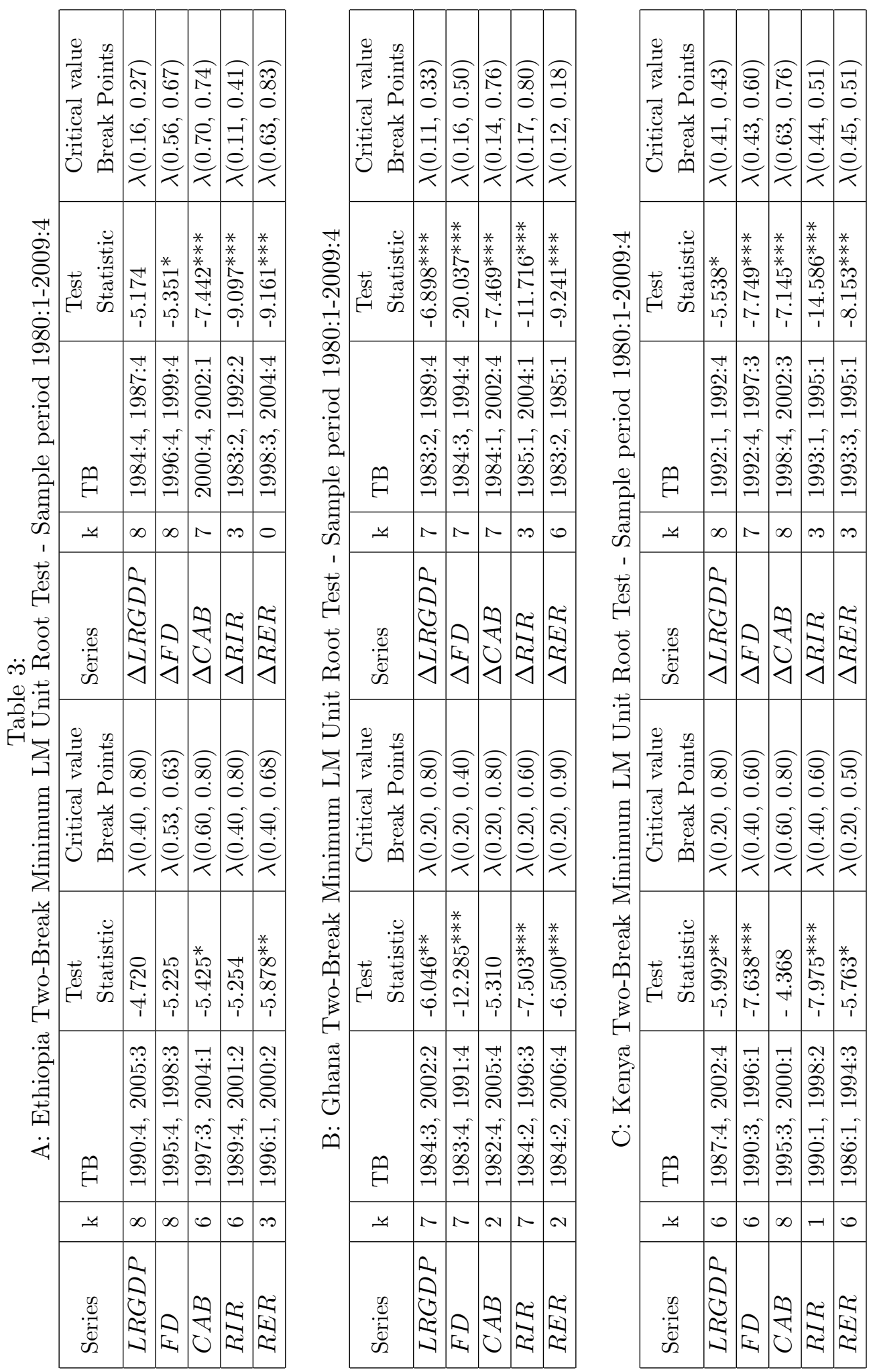

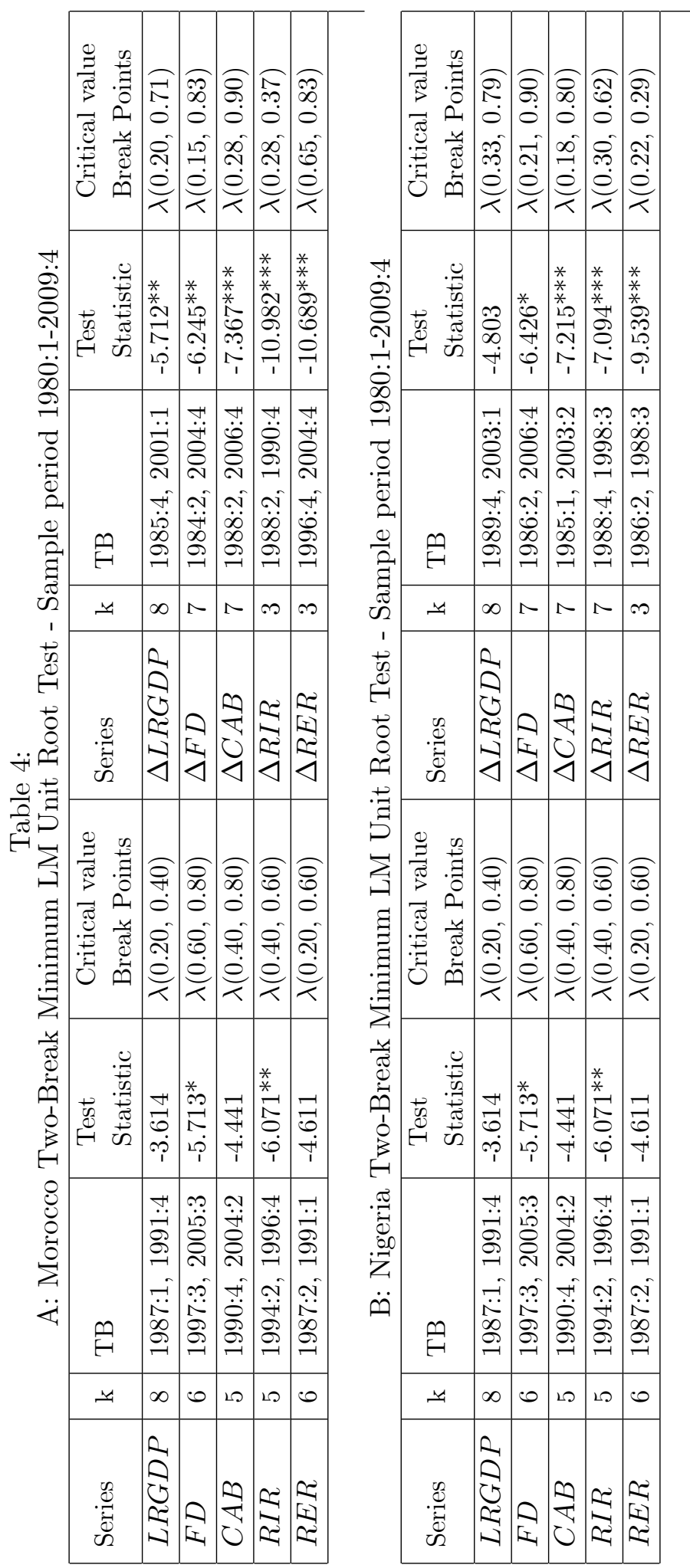

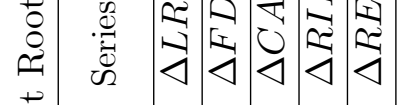
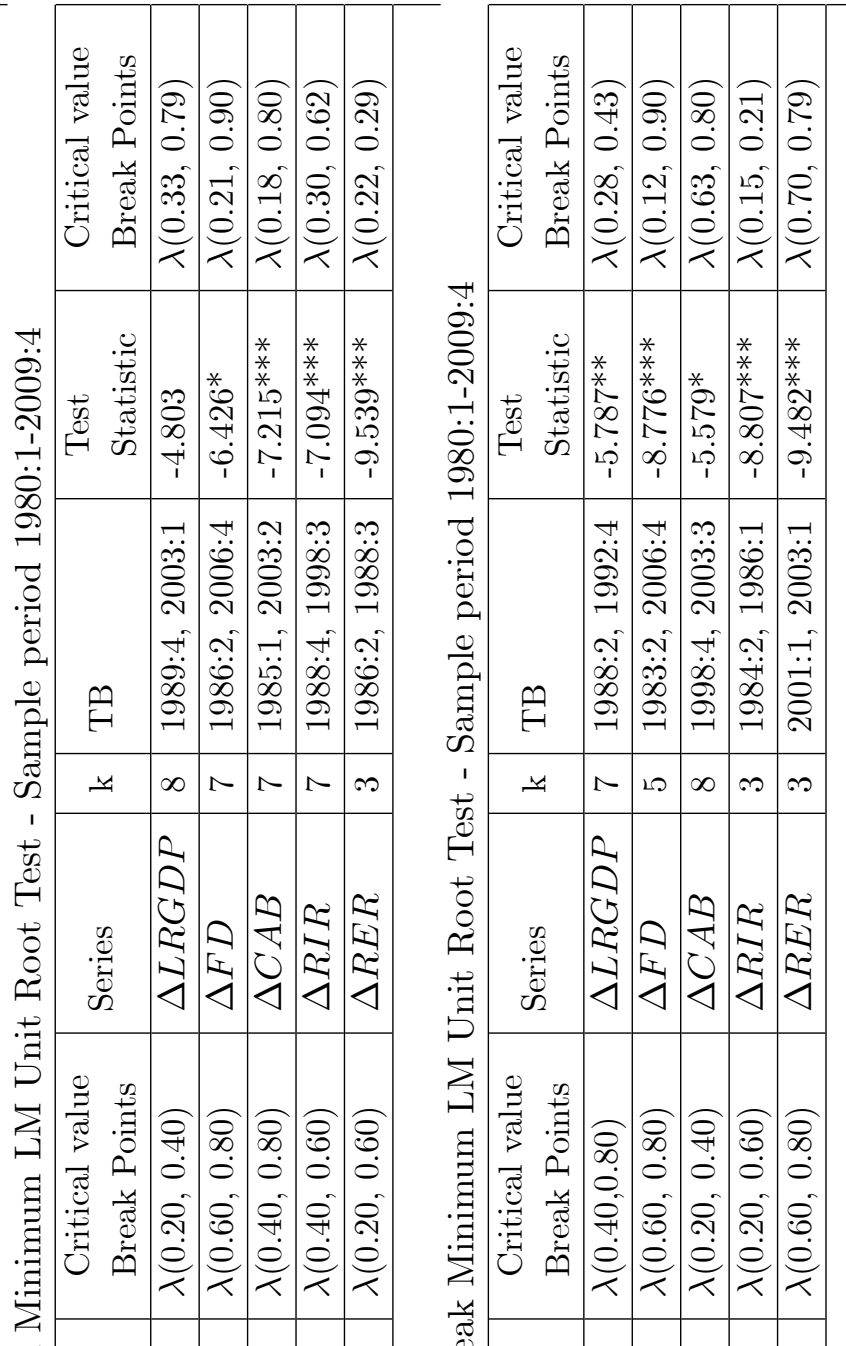

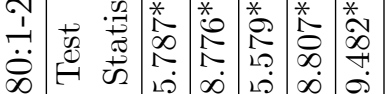

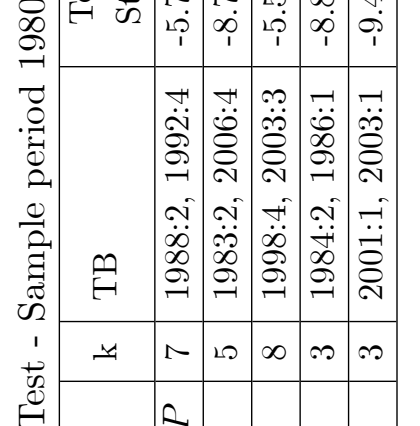

से

至

苯语

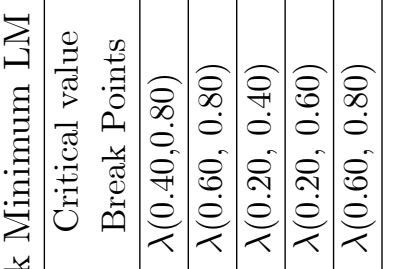

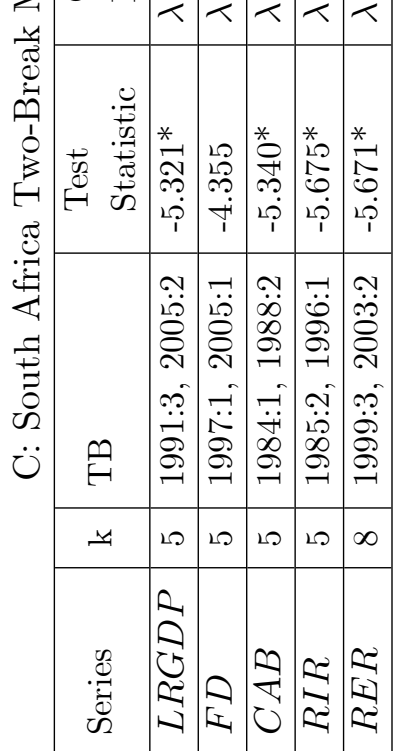



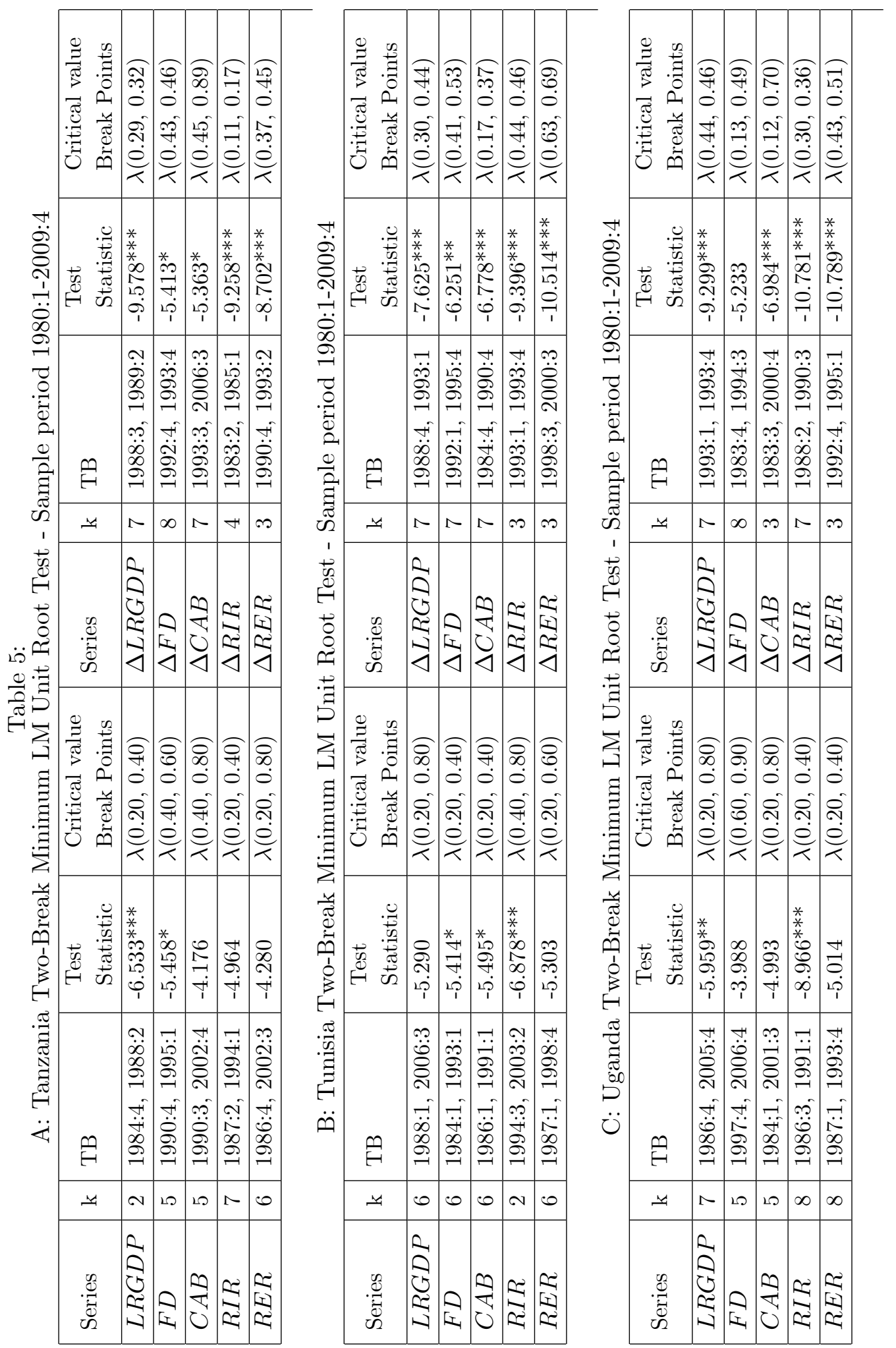
Table 6: Bound Testing for Cointegration Analysis

\begin{tabular}{ll} 
Panel A & $\begin{array}{c}\text { Unrestricted intercept } \\
\text { and no trend }\end{array}$ \\
\hline$F_{\text {cab }}(C A B / L R G D P, F D, R I R, R E R)$ & F-test Statistic \\
Botswana & $5.80^{* * *}$ \\
Cameroon & $4.00^{*}$ \\
Egypt & $8.10^{* * *}$ \\
Ethiopia & $4.92^{* *}$ \\
Ghana & $4.24^{* *}$ \\
Kenya & $4.30^{* *}$ \\
Morocco & $5.03^{* *}$ \\
Nigeria & $6.82^{* * *}$ \\
South Africa & $3.80^{*}$ \\
Tanzania & $5.50^{* * *}$ \\
Tunisia & $5.09^{* *}$ \\
Uganda & $3.90^{*}$ \\
\hline
\end{tabular}

Panel B Critical Values

\begin{tabular}{lrrccc}
\multicolumn{2}{c}{$1 \%$} & \multicolumn{3}{c}{$5 \%$} & \multicolumn{2}{c}{$10 \%$} \\
\hline $\mathrm{I}(0)$ & $\mathrm{I}(1)$ & $\mathrm{I}(0)$ & $\mathrm{I}(1)$ & $\mathrm{I}(0)$ & $\mathrm{I}(1)$ \\
3.817 & 5.122 & 2.850 & 4.049 & 2.425 & 3.574 \\
\hline
\end{tabular}

Note: $* * *$ and $* * *$ indicate level of significance at 10,5 and 1 per cent respectively. Critical values are obtained from Pesaran et al (2001). 
Table 7: Botswana

Panel A Long-Run Coefficients Estimates

Dependent Variable: CAB

\begin{tabular}{llll} 
Regressor & Coefficient & Standard error & T-Ratio \\
\hline LRGDP & -21.593 & 15.016 & -1.438 \\
FD & 0.924 & 0.138 & $6.703^{* * *}$ \\
RIR & 1.621 & 0.374 & $4.335^{* * *}$ \\
RER & -1.638 & 5.071 & -0.323 \\
CONS & 48.193 & 41.811 & 1.153 \\
DU1 & 17.891 & 5.083 & $3.519^{* * *}$ \\
DU2 & 21.201 & 7.279 & $2.912^{* * *}$ \\
\hline \multicolumn{5}{c}{ Panel B Short-Run Coefficients Estimates } \\
Dependent Variable: $\Delta$ CAB \\
Regressor & Coefficient & Standard error & T-Ratio \\
\hline$\Delta C A B_{t-1}$ & 0.557 & 0.073 & $7.583^{* * *}$ \\
$\Delta L R G D P$ & -307.82 & 94.048 & $-3.273^{* * *}$ \\
$\Delta R R G D P_{t-1}$ & 245.311 & 92.102 & $2.664^{* * *}$ \\
$\Delta F D$ & -0.146 & 0.157 & -0.926 \\
$\Delta R I R$ & 0.507 & 0.185 & $2.732^{* * *}$ \\
$\Delta R I R t-1$ & -0.692 & 0.173 & $-3.996^{* * *}$ \\
$\Delta R E R$ & -0.551 & 1.704 & -0.323 \\
$\Delta C O N S$ & 16.221 & 13.482 & 1.203 \\
$\Delta D U 1$ & -7.019 & 2.849 & $-2.464^{* * *}$ \\
$\Delta D U 2$ & -8.101 & 3.904 & $-2.075 * *$ \\
$E C M(-1)$ & -0.337 & 0.046 & $-7.188^{* * *}$ \\
\hline \multicolumn{5}{c}{ Cameroon } \\
\hline
\end{tabular}

Panel A Long-Run Coefficients Estimates

Dependent Variable: CAB

\begin{tabular}{llll} 
Regressor & Coefficient & Standard error & T-Ratio \\
\hline LRGDP & -14.757 & 10.106 & -1.460 \\
FD & 0.048 & 0.062 & 0.778 \\
RIR & -0.141 & 0.081 & $-1.743^{*}$ \\
RER & 1.943 & 1.221 & 1.591 \\
CONS & 40.963 & 33.756 & 1.213 \\
DU1 & 0.382 & 1.171 & 0.326 \\
DU2 & 4.287 & 2.138 & $2.006^{* *}$
\end{tabular}

Panel B Short-Run Coefficients Estimates

Dependent Variable: $\triangle \mathrm{CAB}$

\begin{tabular}{llll} 
Regressor & Coefficient & Standard error & T-Ratio \\
\hline$\Delta C A B_{t-1}$ & 0.492 & 0.085 & $5.776^{* * *}$ \\
$\Delta L R G D P$ & -2.845 & 2.005 & -1.418 \\
$\Delta F D$ & 0.009 & 0.012 & 0.784 \\
$\Delta R I R$ & -0.027 & 0.015 & $-1.837^{*}$ \\
$\Delta R E R$ & 0.375 & 0.232 & 1.615 \\
$\Delta C O N S$ & 7.896 & 6.646 & 1.188 \\
$\Delta D U 1$ & 0.074 & 0.229 & 0.322 \\
$\Delta D U 2$ & 0.826 & 0.465 & $1.779^{*}$ \\
$E C M(-1)$ & -0.193 & 0.043 & $-4.465^{* * *}$ \\
\hline
\end{tabular}

Note: ${ }^{*}{ }^{* *}$ and $* * *$ indicate level of significance at 10,5 and 1 per cent respectively. 
Table 8: Egypt

Panel A Long-run coefficients estimates

Dependent Variable: CAB

\begin{tabular}{llll} 
Regressor & Coefficient & Standard error & T-Ratio \\
\hline LRGDP & 4.229 & 10.044 & 0.421 \\
FD & 0.474 & 0.147 & $3.223 * * *$ \\
RIR & -0.158 & 0.201 & -0.791 \\
RER & 4.583 & 3.184 & 1.439 \\
CONS & -13.789 & 41.445 & -0.333 \\
DU1 & 3.597 & 2.349 & 1.532 \\
DU2 & -5.403 & 4.218 & -1.281 \\
\hline
\end{tabular}

Panel B Short-Run Coefficients Estimates

Dependent Variable: $\triangle \mathrm{CAB}$

\begin{tabular}{llll} 
Regressor & Coefficient & Standard error & T-Ratio \\
\hline$\Delta C A B_{t-1}$ & 0.505 & 0.073 & $6.949^{* * *}$ \\
$\Delta L R G D P$ & 0.451 & 1.078 & 0.418 \\
$\Delta F D$ & -0.078 & 0.039 & $-1.953^{*}$ \\
$\Delta R I R$ & -0.017 & 0.021 & -0.804 \\
$\Delta R E R$ & 0.488 & 0.329 & 1.484 \\
$\Delta R C N S$ & -1.469 & 4.447 & -0.330 \\
$\Delta D U 1$ & 0.383 & 0.261 & 1.471 \\
$\Delta D U 2$ & -0.576 & 0.428 & -1.346 \\
$E C M(-1)$ & -0.107 & 0.022 & $4.871^{* * *}$ \\
\hline \multicolumn{5}{c}{ Ethiopia } \\
\hline
\end{tabular}

\begin{tabular}{|c|c|c|c|}
\hline \multicolumn{4}{|c|}{$\begin{array}{l}\text { Panel A Long-run coefficients estimates } \\
\text { Dependent Variable: CAB }\end{array}$} \\
\hline $\begin{array}{l}\text { Dependent } \\
\text { Regressor }\end{array}$ & $\begin{array}{l}\text { ariable: CAF } \\
\text { Coefficient }\end{array}$ & Standard error & T-Ratio \\
\hline LRGDP & 27.975 & & \\
\hline FD & -0.560 & 0.319 & $-1.758^{*}$ \\
\hline $\begin{array}{l}\mathrm{RMR} \\
\mathrm{RER}\end{array}$ & $\begin{array}{l}0.066 \\
-1.611\end{array}$ & $\begin{array}{l}0.072 \\
1.659\end{array}$ & $\begin{array}{l}0.911 \\
-0.971\end{array}$ \\
\hline CONS & 91.052 & 31.341 & $-2.905^{* * *}$ \\
\hline DU1 & & & \\
\hline DU2 & -14.458 & 3.163 & \\
\hline \multicolumn{4}{|c|}{$\begin{array}{l}\text { Panel B Short-Run Coefficients Estimates } \\
\text { Dependent Variable: } \triangle \mathrm{CAB}\end{array}$} \\
\hline Regressor & Coefficient & Standard error & T-Ratio \\
\hline$\Delta C A B_{t-1}$ & 0.493 & 0.078 & $6.298^{* * *}$ \\
\hline$\triangle L R G D P$ & -18.149 & & \\
\hline$\Delta F D$ & -0.468 & 0.1 & -3.759 \\
\hline$\Delta F D_{t-1}$ & 0.325 & 0.119 & $2.725^{* * *}$ \\
\hline $\begin{array}{l}\Delta R I R \\
\Delta R E R\end{array}$ & $\begin{array}{l}0.012 \\
-0.298\end{array}$ & $\begin{array}{l}0.013 \\
0.295\end{array}$ & $\begin{array}{l}0.959 \\
-1.012\end{array}$ \\
\hline $\bar{\triangle} C O N S$ & -16.857 & & $-3.343^{* * * *}$ \\
\hline$\triangle D U 1$ & -1.244 & 0.3 & $-3.897^{*}$ \\
\hline & -2.4 & & $-3.922^{* *}$ \\
\hline $\operatorname{ECM}(-1)$ & & 0.038 & $-4.833^{* * *}$ \\
\hline
\end{tabular}

Note: ${ }^{*}{ }^{* *}$ and ${ }^{* * *}$ indicate level of significance at 10,5 and 1 per cent respectively. 
Table 9: Ghana

Panel A Long-run coefficients estimates

Dependent Variable: CAB

\begin{tabular}{llll} 
Regressor & \multicolumn{1}{c}{ Coefficient } & Standard error & T-Ratio \\
\hline LRGDP & -6.214 & 12.941 & -0.480 \\
FD & 0.161 & 0.106 & 1.522 \\
RIR & -0.103 & 0.053 & $-1.943^{*}$ \\
RER & -0.616 & 2.004 & -0.307 \\
CONS & 2.579 & 43.187 & 0.059 \\
DU1 & 16.542 & 6.276 & $2.636^{* *}$ \\
DU2 & 18.817 & 6.502 & $2.894^{* * *}$
\end{tabular}

Panel B Short-Run Coefficients Estimates

Dependent Variable: $\triangle \mathrm{CAB}$

Regressor Coefficient Standard error T-Ratio

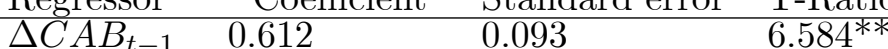

$\begin{array}{llll}\triangle C A B_{t-2} & 0.194 & 0.080 & 2.411^{* *}\end{array}$

$\triangle C A B_{t-3}-0.387$

0.082

1.348

$\triangle C A B_{t-5} \quad 0.287$

$\triangle L R G D P$

$\triangle F D$

0.287

0.093

$-4.168$

$3.015^{*}$

0.107

0.095

$-3.468 * * *$

$\triangle F D_{t-1}$

$\triangle R I R$
$\triangle R E R$

0.001

52.245

$\triangle R E R$
$\triangle C O N S$

$\triangle D U 1$

$-0.104$

0.029

$3.636^{* * *}$
$-3.136^{* * *}$

$\triangle D U 2$

0.435

0.011

0.107

7.339

2.792

0.913

$-0.309$

0.059

ECM(-1)

1.081

$3.059^{* * *} *$
$2.938^{* * *}$

Kenya $-3.741^{* * *}$

\begin{tabular}{llll}
\multicolumn{4}{l}{ Panel A Long-run coefficients estimates } \\
$\begin{array}{l}\text { Dependent } \\
\text { Regressor }\end{array}$ & $\begin{array}{l}\text { Coefficient } \\
\text { Coble: CAB }\end{array}$ & Standard error & T-Ratio \\
\hline LRGDP & -49.439 & 14.095 & $-3.508^{* * *}$ \\
FD & -0.525 & 0.263 & $-1.994^{*}$ \\
RIR & -0.021 & 0.121 & -1.172 \\
RER & 0.443 & 3.713 & 0.119 \\
CONS & 157.568 & 46.969 & $3.355^{* * *}$ \\
DU1 & 9.946 & 3.954 & $2.516^{* *}$ \\
DU2 & 14.801 & 4.138 & $3.577^{* * *}$ \\
\hline Panel B Short-Run Coefficients Estimates & \\
Dependent Variable: $\triangle \mathrm{CAB}$ & & \\
Regressor & Coefficient & Standard error & T-Ratio \\
\hline$\Delta C A B t-1$ & 0.424 & 0.083 & $5.102^{* * *}$ \\
$\Delta L R G D P$ & -7.945 & 2.572 & $-3.089^{* * *}$ \\
$\Delta F D$ & -0.622 & 0.177 & $-3.509^{* * *}$ \\
$\Delta R I R$ & -0.003 & 0.019 & -0.171 \\
$\Delta R E R$ & 0.071 & 0.597 & 0.119 \\
$\Delta C O N S$ & 25.321 & 8.401 & $3.014^{* * *}$ \\
$\Delta D U 1$ & 1.598 & 0.618 & $2.587^{* *}$ \\
$\Delta D U 2$ & 2.378 & 0.794 & $2.995^{* *}$ \\
$E C M(-1)$ & -0.161 & 0.035 & $-4.567^{* * *}$ \\
\hline
\end{tabular}

Note: ${ }^{* * *}$ and $* * *$ indicate level of significance at 10,5 and 1 per cent respectively. 
Table 10: Morocco

Panel A Long-run coefficients estimates

Dependent Variable: CAB

\begin{tabular}{llll} 
Regressor & \multicolumn{1}{c}{ Coefficient } & Standard error & T-Ratio \\
\hline LRGDP & 36.149 & 8.505 & $4.250^{* * *}$ \\
FD & 0.032 & 0.221 & 0.142 \\
RIR & 0.836 & 0.235 & $3.556^{* * *}$ \\
RER & -2.534 & 1.769 & -1.432 \\
CONS & -138.626 & 31.788 & $-4.361^{* * *}$ \\
DU1 & -4.534 & 2.301 & $-1.970^{*}$ \\
DU2 & -13.922 & 3.873 & $-3.595^{* * *}$ \\
\hline
\end{tabular}

Panel B Short-Run Coefficients Estimates

Dependent Variable: $\triangle \mathrm{CAB}$

\begin{tabular}{llll} 
Regressor & \multicolumn{1}{c}{ Coefficient } & Standard error & T-Ratio \\
\hline$\Delta C A B_{t-1}$ & 0.492 & 0.077 & $6.355^{* * *}$ \\
$\Delta L R G D P$ & 22.616 & 7.976 & $2.836^{* *}$ \\
$\Delta F D$ & 0.508 & 0.104 & $4.894^{* * *}$ \\
$\Delta F D_{t-1}$ & -0.381 & 0.112 & $-3.397^{* * *}$ \\
$\Delta R I R$ & 0.109 & 0.032 & $3.414^{* * *}$ \\
$\Delta R E R$ & -0.332 & 0.229 & -1.451 \\
$\Delta C O N S$ & -18.167 & 4.987 & $-3.643^{* * *}$ \\
$\Delta D U 1$ & -0.594 & 0.285 & $-2.085^{* *}$ \\
$\Delta D U 2$ & -1.825 & 0.535 & $-3.411^{* * *}$ \\
$E C M(-1)$ & -0.131 & 0.026 & $-4.980^{* * *}$
\end{tabular}

Panel A Long-run coefficients estimates

Dependent Variable: CAB

\begin{tabular}{llll} 
Regressor & \multicolumn{1}{c}{ Coefficient } & Standard error & T-Ratio \\
\hline LRGDP & -41.821 & 31.497 & -1.328 \\
FD & 0.349 & 0.174 & $2.012^{* *}$ \\
RIR & 0.096 & 0.138 & 0.698 \\
RER & 0.962 & 5.137 & 0.187 \\
CONS & 153.769 & 121.763 & 1.263 \\
DU1 & 10.913 & 5.387 & $2.026^{* *}$ \\
DU2 & 33.212 & 9.441 & $3.518^{* * *}$
\end{tabular}

Panel B Short-Run Coefficients Estimates

Dependent Variable: $\triangle \mathrm{CAB}$

\begin{tabular}{llll} 
Regressor & \multicolumn{1}{c}{ Coefficient } & Standard error & T-Ratio \\
\hline$\Delta C A B_{t-1}$ & 0.568 & 0.068 & $8.394^{* * *}$ \\
$\Delta L R G D P$ & -6.351 & 4.986 & -1.274 \\
$\Delta F D$ & 0.207 & 0.063 & $3.305^{* * *}$ \\
$\Delta R I R$ & 0.015 & 0.021 & 0.683 \\
$\Delta R E R$ & 0.146 & 0.783 & 0.187 \\
$\Delta C O N S$ & 23.352 & 19.213 & 1.216 \\
$\Delta D U 1$ & 1.657 & 0.863 & $1.921^{*}$ \\
$\Delta D U 2$ & 5.044 & 1.663 & $3.032^{* * *}$ \\
$E C M(-1)$ & -0.152 & 0.032 & $-4.702^{* * *}$ \\
\hline
\end{tabular}

Note: ${ }^{* * *}$ and ${ }^{* * *}$ indicate level of significance at 10,5 and 1 per cent respectively. 
Table 11: South Africa

Panel A Long-run coefficients estimates

Dependent Variable: CAB

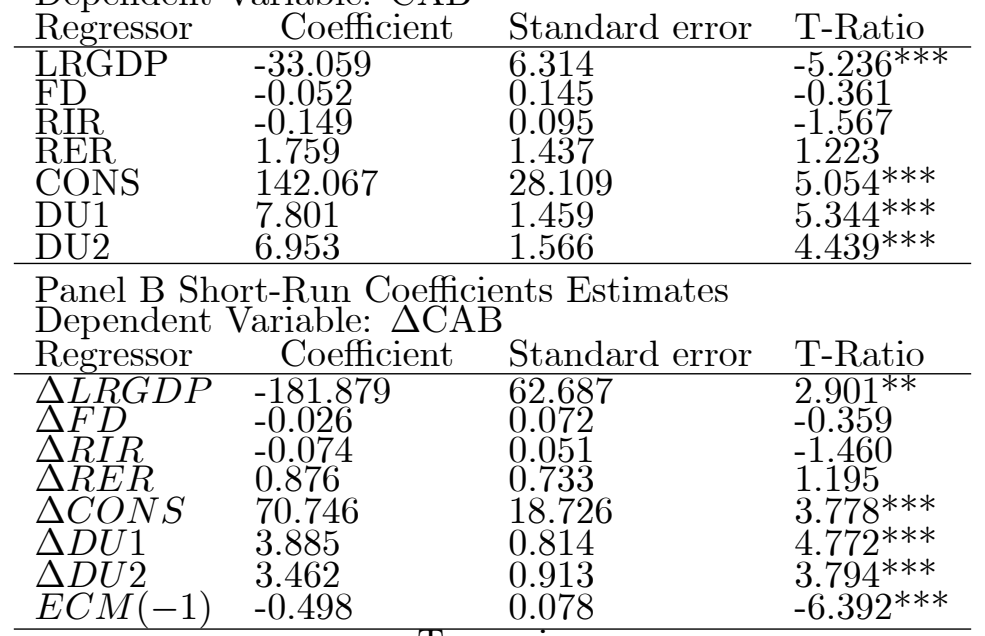

Panel A Long-run coefficients estimates

Dependent Variable: CAB

\begin{tabular}{llll} 
Regressor & Coefficient & Standard error & T-Ratio \\
\hline LRGDP & -10.466 & 25.540 & -0.409 \\
FD & 2.143 & 1.252 & $1.711^{*}$ \\
RIR & -0.172 & 0.349 & -0.490 \\
RER & -15.287 & 10.341 & -1.478 \\
CONS & 34.607 & 77.849 & 0.445 \\
DU1 & 36.059 & 16.211 & $2.224^{* *}$ \\
DU2 & 36.037 & 19.231 & $1.874^{*}$ \\
\hline
\end{tabular}

Panel B Short-Run Coefficients Estimates

Dependent Variable: $\triangle \mathrm{CAB}$

\begin{tabular}{llll} 
Regressor & Coefficient & Standard error & T-Ratio \\
\hline$\Delta C A B_{t-1}$ & 0.338 & 0.079 & $4.271^{* * *}$ \\
$\Delta L R G D P$ & 15.746 & 2.692 & $5.849^{* * *}$ \\
$\Delta F D$ & -0.409 & 0.093 & $-4.380^{* * *}$ \\
$\Delta R I R$ & -0.008 & 0.016 & -0.476 \\
$\Delta R E R$ & -0.698 & 0.339 & $-2.058^{* *}$ \\
$\Delta C O N S$ & 1.581 & 3.412 & 0.464 \\
$\Delta D U 1$ & 1.648 & 0.321 & $5.129^{* * *}$ \\
$\Delta D U 2$ & 1.647 & 0.475 & $3.469^{* * *}$ \\
$E C M(-1)$ & -0.046 & 0.018 & $-2.532^{* *}$ \\
\hline
\end{tabular}

Note: ${ }^{*}{ }^{* *}$ and ${ }^{* * *}$ indicate level of significance at 10,5 and 1 per cent respectively. 
Table 12: Tunisia

Panel A Long-run coefficients estimates Dependent Variable: CAB

\begin{tabular}{|c|c|c|c|}
\hline Regressor & Coefficient & Standard error & T-Ratio \\
\hline LRGDP & 1.673 & 6.497 & 0.258 \\
\hline FD & 0.350 & 0.468 & 0.748 \\
\hline RIR & -0.470 & 0.332 & -1.417 \\
\hline$\overline{\mathrm{R}} \overline{\mathrm{ER}}$ & 0.996 & 2.005 & 0.497 \\
\hline CONS & -12.722 & 22.506 & -0.565 \\
\hline DU1 & 6.263 & 1.694 & $3.694^{* * *}$ \\
\hline DU2 & 4.739 & 2.797 & $1.695^{*}$ \\
\hline \multirow{2}{*}{\multicolumn{4}{|c|}{ Panel B Short-Run Coefficients Estimates }} \\
\hline \multirow{2}{*}{\multicolumn{4}{|c|}{$\begin{array}{l}\text { Dependent variable: } \\
\text { Regressor }\end{array}$}} \\
\hline & & & \\
\hline$\triangle C A B_{t-1}$ & 0.627 & 0.075 & $8.345^{* * *}$ \\
\hline$\triangle L R G D P$ & 78.731 & 18.141 & $4.340^{* * *}$ \\
\hline$\triangle L R G D P_{t-1}$ & -53.921 & 19.009 & $-2.837^{* *}$ \\
\hline$\Delta F D$ & $\begin{array}{l}0.055 \\
-0.074\end{array}$ & $\begin{array}{l}0.072 \\
0.059\end{array}$ & $\begin{array}{l}0.765 \\
-1.247\end{array}$ \\
\hline$\triangle R E R$ & 0.157 & 0.331 & 0.474 \\
\hline$\triangle C O N S$ & -2.001 & 3.455 & -0.579 \\
\hline$\triangle D U 1$ & 0.985 & 0.377 & $2.616^{* *}$ \\
\hline$\triangle D \cup 2$ & 0.746 & 0.497 & 1.502 \\
\hline \multicolumn{4}{|c|}{ Uganda } \\
\hline \multirow{2}{*}{\multicolumn{4}{|c|}{$\begin{array}{l}\text { Panel A Long-run coefficients estimates } \\
\text { Dependent Variable: CAB }\end{array}$}} \\
\hline & & & \\
\hline Regressor & Coefficient & Standard error & T-Ratio \\
\hline LRGDP & -18.291 & 5.680 & $-3.220^{* * *}$ \\
\hline & -0.518 & 0.344 & -1.504 \\
\hline RIR & 0.015 & 0.013 & 1.098 \\
\hline RER & -1.138 & 0.748 & -1.521 \\
\hline DU1 & 4.269 & $\begin{array}{l}10.000 \\
2.453\end{array}$ & $1.741^{*}$ \\
\hline DU2 & 14.916 & 3.504 & $4.257 * *$ \\
\hline
\end{tabular}

Panel B Short-Run Coefficients Estimates

Dependent Variable: CAB

\begin{tabular}{llll} 
Regressor & Coefficient & Standard error & T-Ratio \\
\hline$\Delta C A B_{t-1}$ & 0.522 & 0.063 & $7.487^{* * *}$ \\
$\Delta L R G D P$ & -56.851 & 12.931 & $-4.397^{* * *}$ \\
$\Delta L R G D P_{t-1}$ & 32.349 & 13.439 & $2.407^{* *}$ \\
$\Delta F D$ & -0.071 & 0.049 & -1.454 \\
$\Delta R I R$ & 0.002 & 0.001 & 1.116 \\
$\Delta R E R$ & -0.156 & 0.105 & -1.487 \\
$\Delta C O N S$ & 6.526 & 2.376 & $2.746^{* *}$ \\
$\Delta D U 1$ & 0.587 & 0.356 & 1.649 \\
$\Delta D U 2$ & 2.051 & 0.563 & $3.641^{* * *}$ \\
$E C M(-1)$ & -0.137 & 0.024 & $-5.750^{* * *}$ \\
\hline
\end{tabular}

Note: ${ }^{*}, *$ and ${ }^{* * *}$ indicate level of significance at 10,5 and 1 per cent respectively. 


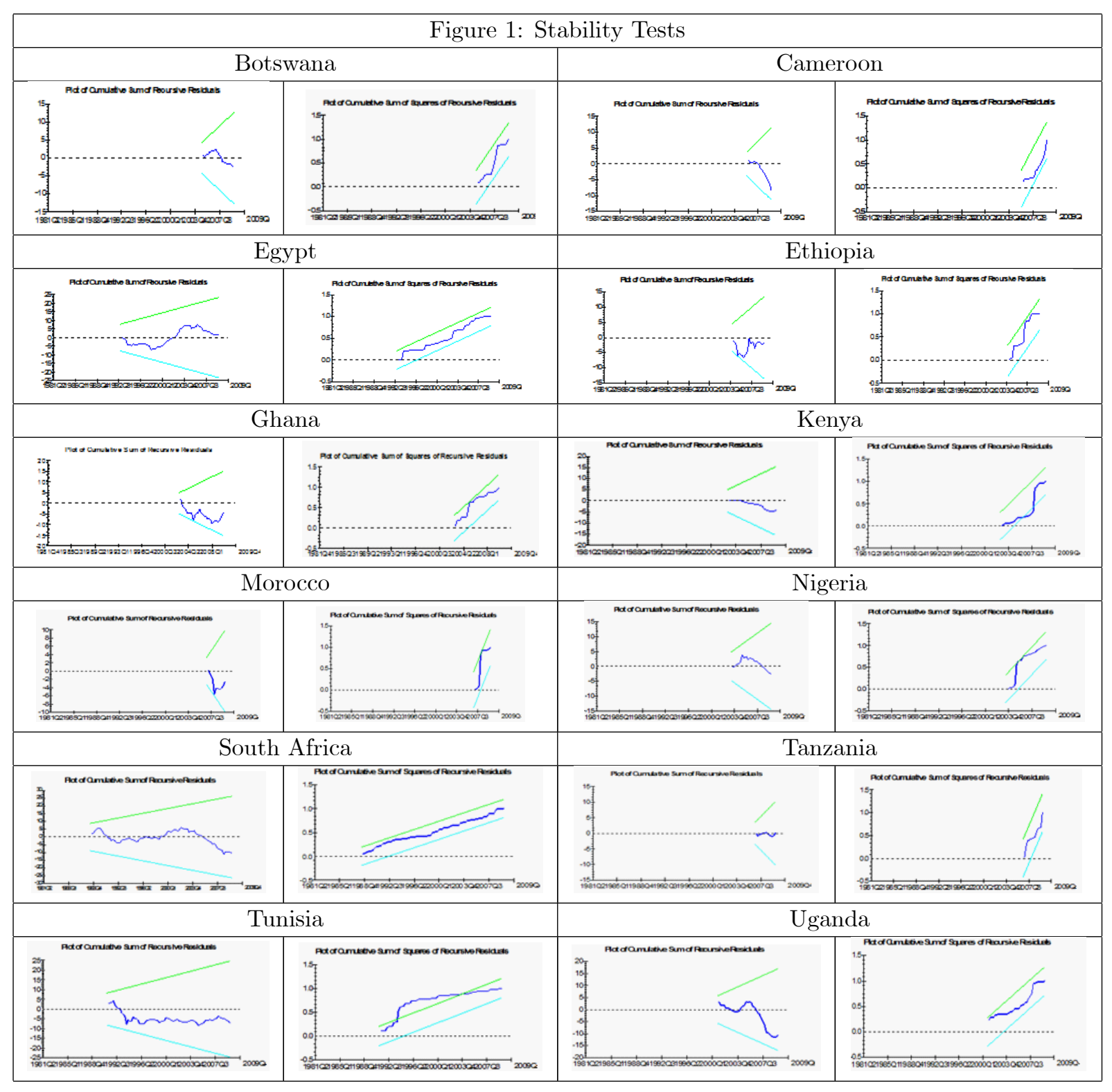

